\title{
PERILAKU PENGGUNA DAN INFORMASI HOAX DI MEDIA SOSIAL
}

\author{
Dedi Rianto Rahadi ${ }^{*}$ \\ ${ }^{1}$ Fakultas Ekonomi dan Bisnis, Universitas Presiden \\ *dedi1968@president.ac.id
}

\begin{abstract}
:
User behavior in sosial media and hoax information are an interesting phenomenon today. Social media is the most effective medium in Hoax's acceptance and dissemination of information. Various backgrounds of user behavior becomes one of the factors that make it easier for them to disseminate information without going through the verification process. Research method uses a qualitative descriptive method with research object of civitas academic environment of President University. The results shows the behavior of social media users in responding Hoax information is quite diverse with a variety of user backgrounds. Users understand the Hoax information and impacts that arise after disseminating the information. The main reason the users spread the information Hoax is to influence the opinions/ attitudes of others. The other reason is to become a viral Social media users also understand that Hoax information can divide the nation. To inhibit the dissemination of hoax information, the role of government and parents is needed as well as the literacy/education of social media usage so that user behavior will be wise in responding to all information received.
\end{abstract}

Keywords: User behavior, hoax information, social media

\section{PENDAHULUAN}

Saat ini media sosial merupakan media komunikasi yang efektif, tranparasi dan efisien serta memiliki peran penting sebagai agen perubahan dan pembaharuan. Penggunaan media sosial sebagai jembatan untuk membantu proses peralihan masyarakat yang tradisional ke masyarakat yang modern, khususnya untuk mentransfer informasi pembangunan yang dilaksanakan pemerintah kepada masyarakatnya. Sebaliknya masyarakat dapat menyampaikan informasi langsung kepada pemerintah tentang berbagai hal terkait dengan pelayanan yang diterima. Menurut Taprial dan Kanwar (2012), media sosial adalah media yang digunakan oleh individu agar menjadi sosial, secara daring dengan cara berbagi isi, berita, foto dan lain-lain dengan orang lain. Dari definisi tersebut jelas bahwa masyarakat dapat berbagi informasi dan sebaliknya kepada pemerintah. Pada gambar 1 memperlihatkan contoh pengaduan dan media yang digunakan dengan menggunakan Istagram.
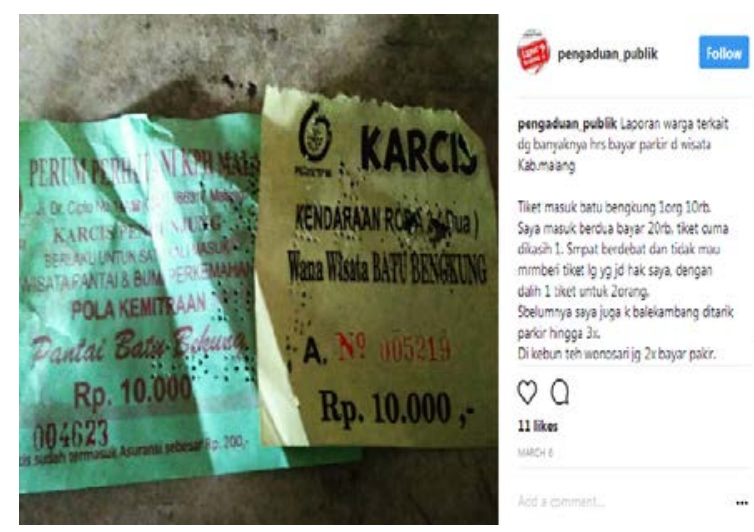


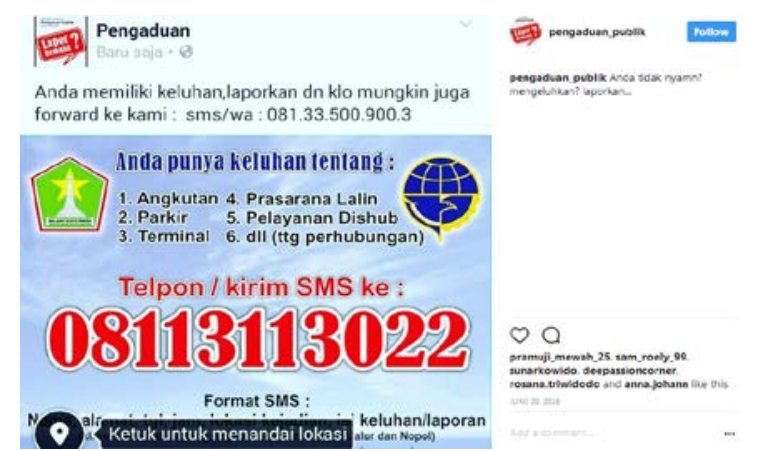

Gambar 1. Pengaduan Masyarakat dan Media Pemerintah Melalui Istagram

Pada era keterbukaan dewasa ini peran media sosial dibutuhkan oleh pemerintah diantaranya membantu penyelesaian pengaduan atau laporan pelayanan publik, membantu peningkatan partisipasi masyarakat dalam pengawasan pelayanan publik dan mempercepat penyelesaian laporan pelayanan publik. Media sosial mempunyai peranan strategis selain sebagai transformasi informasi, media sosial juga dapat menjadi sarana komunikasi antar sesama masyarakat maupun antara masyarakat dengan pemerintah dalam menyampaikan keluhan maupun menyampaikan berbagai aspirasi. Banyaknya media online dan media sosial yang menawarkan berbagai akses kemudahan akan lebih efektif dan bermanfaat bila dijadikan sebagai wadah dalam memberikan masukan, kritik maupun saran dalam pembangunan. Disisi lain perlu adanya dorongan kepada semua lapisan masyarakat agar memiliki etika bagaimana memanfaatkan media sosial. Banyak sekali pengguna media sosial yang memanfaatkan media ini untuk hal-hal yang sifatnya negatif dan dapat merugikan semua pihak, baik itu pemerintah maupun masyarakat itu sendiri.

Permasalah yang timbul dari penggunaan media sosial saat ini adalah banyaknya hoax yang menyebar luas, bahkan orang terpelajar pun tidak bisa bedakan mana berita yang benar, advertorial dan hoax. Penyebaran tanpa dikoreksi maupun dipilah, pada akhirnya akan berdampak pada hukum dan informasi hoax-pun telah memecah belah publik. Gambar 2 memperlihatkan contoh informasi hoax dari media sosial.

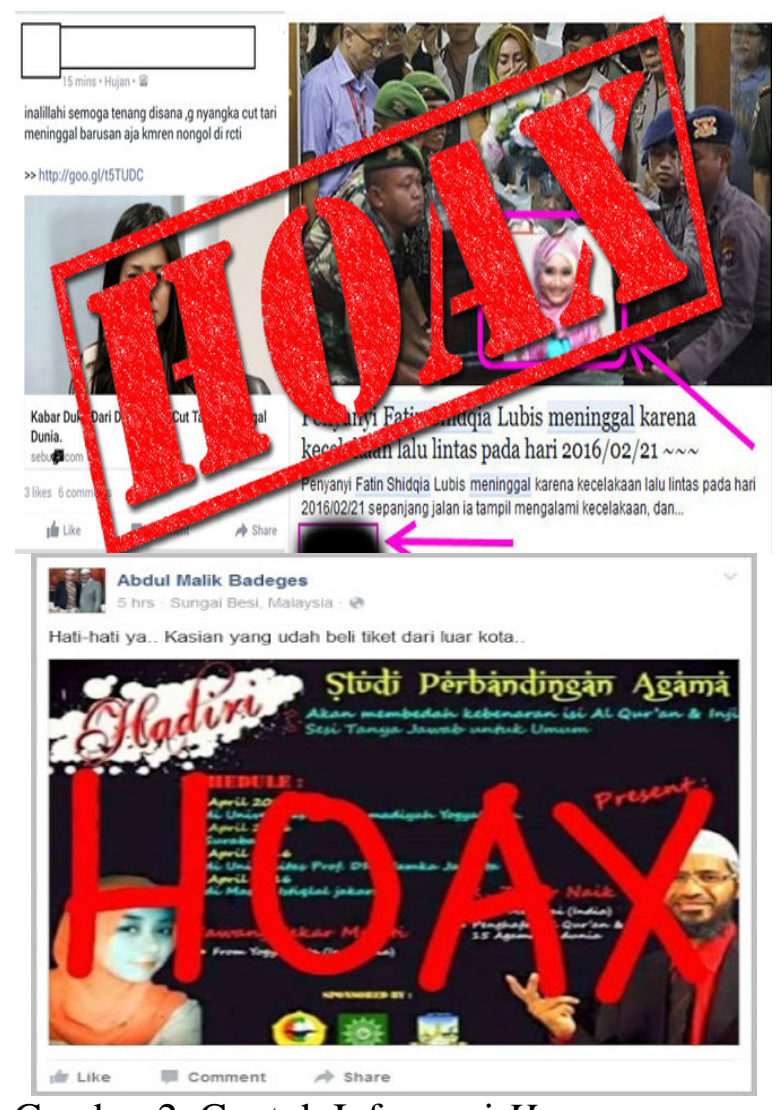

Gambar 2. Contoh Informasi Hoax

Masyarakat diharapkan lebih bijak dalam memanfaatkan media sosial. Misalnya, memastikan terlebih dahulu akurasi konten yang akan dibagikan, mengklarifikasi kebenarannya, memastikan manfaatnya, baru kemudian menyebarkannya. Adapun perumusan masalah dalam penelitian adalah bagaimana memanfaatkan media sosial serta meminimalisir informasi hoax sebagai sarana untuk bertukar informasi dengan pemerintah. Tujuan penelitian untuk mengetahui dan menganalisis manfaat media sosial dan antisipasi hoax dalam bertukar informasi dengan pemerintah

\section{Tinjauan Pustaka \\ Media Sosial}

Media sosial merupakan sarana efektif dan efisien dalam menyampaikan suatu informasi kepada pihak lain. Media sosial sebagai media dengan dinamika sosial yang sangat tinggi dan memungkinkan komunikasi terbuka kepada berbagai pihak dengan beragam latar belakang dan 
kepentingan adalah sarana yang tepat untuk membangkitkan partisipasi warga dalam membangun kota. Seperti yang dikemukan Howard dan Parks (2012) Media sosial adalah media yang terdiri atas tiga bagian, yaitu : Insfrastruktur informasi dan alat yang digunakan untuk memproduksi dan mendistribusikan isi media, Isi media dapat berupa pesan-pesan pribadi, berita, gagasan, dan produk-produk budaya yang berbentuk digital, Kemudian yang memproduksi dan mengkonsumsi isi media dalam bentuk digital adalah individu, organisasi, dan industri. Kotler dan Keller (2009) juga mengemukakan media sosial adalah media yang digunakan oleh konsumen untuk berbagi teks, gambar, suara, dan video informasi baik dengan orang lain maupun perusahaan dan vice versa. Pendapat tersebut didukung pernyataan Carr dan Hayes (2015) dimana media sosial adalah media berbasis internet yang memungkinkan pengguna berkesempatan untuk berinteraksi dan mempresentasikan diri, baik secara seketika ataupun tertunda, dengan khalayak luas maupun tidak yang mendorong nilai dari user-generated content dan persepsi interaksi dengan orang lain. Media sosial digunakan secara produktif oleh seluruh ranah masyarakat, bisnis, politik, media, periklanan, polisi, dan layanan gawat darurat. Media sosial telah menjadi kunci untuk memprovokasi pemikiran, dialog, dan tindakan seputar isu-isu sosial.

\section{Jenis Media Sosial}

Kaplan dan Haenlein (2010) membagi berbagai jenis media sosial ke dalam 6 (enam) jenis, yaitu

1. Collaborative Projects, yaitu suatu media sosial yang dapat membuat konten dan dalam pembuatannya dapat diakses khalayak secara global. Kategori yang termasuk dalam Collaborative Projects dalam media sosial, yaitu WIKI atau Wikipedia yang sekarang sangat populer di berbagai negara. Collaborative Projects ini dapat dimanfaatkan untuk mendukung citra perusahaan, terlepas dari pro-kontra soal kebenaran isi materi dalam situs tersebut.

2. Blogs and Microblogs, yaitu aplikasi yang dapat membantu penggunanya untuk menulis secara runut dan rinci mengenai berita, opini, pengalaman, ataupun kegiatan sehari-hari, baik dalam bentuk teks, gambar, video, ataupun gabungan dari ketiganya. Kedua aplikasi ini mempunyai peran yang sangat penting baik dalam penyampaian informasi maupun pemasaran produk. Melalui kedua aplikasi tersebut, pihak pengguna dengan leluasa dapat mengiring opini masyarakat atau pengguna internet untuk lebih dekat dengan mereka tanpa harus bersusah-susah menyampaikan informasi secara tatap muka.

3. Content Communities, yaitu sebuah aplikasi yang bertujuan untuk saling berbagi dengan seseorang baik secara langsung maupun tidak langsung, di mana dalam aplikasi ini user atau penggunanya dapat berbagi video, ataupun foto. Sosial media ini dapat dimanfaatkan untuk mempublikasikan suatu bentuk kegiatan positif yang dilakukan oleh satu perusahaan, sehingga kegiatan tersebut akan mendapatkan perhatian khalayak dan pada akhirnya akan membangun citra positif bagi perusahaan.

4. Social Networking Sites atau Situs Jejaring Sosial, yaitu merupakan situs yang dapat membantu seseorang atau pengguna internet membuat sebuah profil dan menghubungkannya dengan pengguna lain. Situs jejaring sosial memungkinkan penggunanya mengunggah hal-hal yang sifatnya pribadi seperti foto, video, koleksi tulisan, dan saling berhubungan secara pribadi dengan pengguna lainnya melalui private pesan yang hanya bisa diakses dan diatur pemilik akun tersebut. Situs jejaring sosial sangat berperan dalam hal membangun dan membentuk brand image, karena sifatnya yang interaktif sehingga pengguna dapat dengan mudah mengirim dan menerima informasi, bahkan dapat digunakan sebagai media komunikasi dan 
klarifikasi yang nyaman antara pemilik produk dengan konsumennya.

5. Virtual Game Worlds, yaitu permainan multiplayer di mana ratusan pemain secara simultan dapat di dukung. Media sosial ini sangat mendukung dalam hal menarik perhatian konsumen untuk tahu lebih banyak dengan desain grafis yang mencolok dan permainan warna yang menarik, sehingga terasa lebih informatif dan interaktif.

6. Virtual Social Worlds, yaitu aplikasi yang mensimulasi kehidupan nyata dalam internet. Aplikasi ini menungkinkan pengguna berinteraksi dalam platform tiga dimensi menggunakan avatar yang mirip dengan kehidupan nyata. Aplikasi ini sangat membantu dalam menerapkan suatu strategi pemasaran atau penyampaian informasi secara interaktif serta menarik.

\section{Fungsi Media Sosial}

Fungsi media sosial dapat diketahui melalui sebuah kerangka kerja honeycomb. Menurut Kietzmann, etl (2011) menggambarkan hubungan kerangka kerja honeycomb sebagai penyajian sebuah kerangka kerja yang mendefinisikan media sosial dengan menggunakan tujuh kotak bangunan fungsi yaitu identity, cenversations, sharing, presence, relationships, reputation, dan groups.

1. Identity menggambarkan pengaturan identitas para pengguna dalam sebuah media sosial menyangkut nama, usia, jenis kelamin, profesi, lokasi serta foto.

2. Conversations menggambarkan pengaturan para pengguna berkomunikasi dengan pengguna lainnya dalam media sosial.

3. Sharing menggambarkan pertukaran, pembagian, serta penerimaan konten berupa teks, gambar, atau video yang dilakukan oleh para pengguna.

4. Presence menggambarkan apakah para pengguna dapat mengakses pengguna lainnya.
5. Relationship menggambarkan para pengguna terhubung atau terkait dengan pengguna lainnya.

6. Reputation menggambarkan para pengguna dapat mengidentifikasi orang lain serta dirinya sendiri.

7. Groups menggambarkan para pengguna dapat membentuk komunitas dan subkomunitas yang memiliki latar belakang, minat, atau demografi.

\section{Informasi Hoax}

Hoax adalah usaha untuk menipu atau mengakali pembaca/pendengarnya untuk mempercayai sesuatu, padahal sang pencipta berita palsu tersebut tahu bahwa berita tersebut adalah palsu. Salah satu contoh pemberitaan palsu yang paling umum adalah mengklaim sesuatu barang atau kejadian dengan suatu sebutan yang berbeda dengan barang/ kejadian sejatinya. Definisi lain menyatakan hoax adalah suatu tipuan yang digunakan untuk mempercayai sesuatu yang salah dan seringkali tidak masuk akal yang melalui media online (https://www.merriamwebster. com)

Hoax bertujuan untuk membuat opini publik, menggiring opini publik, membentuk persepsi juga untuk hufing fun yang menguji kecerdasan dan kecermatan pengguna internet dan media sosial. Tujuan penyebaran hoax beragam tapi pada umumnya hoax disebarkan sebagai bahan lelucon atau sekedar iseng, menjatuhkan pesaing (black campaign), promosi dengan penipuan, ataupun ajakan untuk berbuat amalan amalan baik yang sebenarnya belum ada dalil yang jelas di dalamnya. Namun ini menyebabkan banyak penerima hoax terpancing untuk segera menyebarkan kepada rekan sejawatnya sehingga akhirnya hoax ini dengan cepat tersebar luas.

Orang lebih cenderung percaya hoax jika informasinya sesuai dengan opini atau sikap yang dimiliki (Respati, 2017). Contohnya jika seseorang penganut paham bumi datar memperoleh artikel yang membahas tentang berbagai teori konspirasi mengenai foto satelit maka secara naluri orang tersebut akan mudah percaya karena 
mendukung teori bumi datar yang diyakininya. Secara alami perasaan positif akan timbul dalam diri seseorang jika opini atau keyakinannya mendapat afirmasi sehingga cenderung tidak akan mempedulikan apakah informasi yang diterimanya benar dan bahkan mudah saja bagi mereka untuk menyebarkan kembali informasi tersebut. Hal ini dapat diperparah jika si penyebar hoax memiliki pengetahuan yang kurang dalam memanfaatkan internet guna mencari informasi lebih dalam atau sekadar untuk cek dan ricek fakta.

\section{Jenis-jenis Informasi Hoax}

1. Fake news: Berita bohong: Berita yang berusaha menggantikan berita yang asli. Berita ini bertujuan untuk memalsukan atau memasukkan ketidakbenaran dalam suatu berita. Penulis berita bohong biasanya menambahkan hal-hal yang tidak benar dan teori persengkokolan, makin aneh, makin baik. Berita bohong bukanlah komentar humor terhadap suatu berita.

2. Clickbait: Tautan jebakan: Tautan yang diletakkan secara stategis di dalam suatu situs dengan tujuan untuk menarik orang masuk ke situs lainnya. Konten di dalam tautan ini sesuai fakta namun judulnya dibuat berlebihan atau dipasang gambar yang menarik untuk memancing pembaca.

3. Confirmation bias : Bias konfirmasi: Kecenderungan untuk menginterpretasikan kejadian yang baru terjadi sebaik bukti dari kepercayaan yang sudah ada.

4. Misinformation: Informasi yang salah atau tidak akurat, terutama yang ditujukan untuk menipu.

5. Satire: Sebuah tulisan yang menggunakan humor, ironi, hal yang dibesar-besarkan untuk mengkomentari kejadian yang sedang hangat. Berita satir dapat dijumpai di pertunjukan televisi seperti "Saturday Night Live" dan "This Hour has 22 Minutes".

6. Post-truth: Pasca-kebenaran: Kejadian di mana emosi lebih berperan daripada fakta untuk membentuk opini publik.
7. Propaganda: Aktifitas menyebar luaskan informasi, fakta, argumen, gosip, setengah-kebenaran, atau bahkan kebohongan untuk mempengaruhi opini publik.

\section{METODE}

Metode penelitian yang digunakan adalah metode deskriptif kualitatif dirancang untuk mengumpulkan informasi tentang keadaan-keadaan yang sementara berlangsung. Penelitian deskriptif kualitatif adalah suatu metode dalam meneliti status sekelompok manusia, suatu objek dengan tujuan membuat deskriptif, gambaran atau lukisan secara sistematis, faktual dan akurat mengenai fakta-fakta atau fenomena yang diselidiki (Convelo G. Cevilla, dkk, 1993). Informan dalam penelitian adalah pengguna yang memiliki media sosial dan pernah menerima informasi hoax, dengan jumlah pengguna sebanyak 122 orang dan dipilih secara acak dari beberapa profesi yang dilingkungan civitas akademik Universitas Presiden.

\section{HASIL}

Hasil penelitian menunjukkan hasil sebagai berikut : Profesi responden menunjukkan 42 responden sebagai pekerja baik sebagai pegawai dan dosen, 24 responden sebagai wirausahawan, 43 respoden sebagai mahasiswa, serta 13 responden tidak memiliki pekerjaan. Pertanyaan diawali dengan " Apakah saudara memiliki akun media sosial ?”. Jawaban responden $100 \%$ memiliki akun di media sosial. Pertanyaan berikutnya "akun media sosial apa saja yang anda miliki ?” Jawaban responden mereka memiliki lebih dari satu akun mulai dari WA, Line, Facebook, Instagram, Path, Twitter. Pertanyaan berikutnya “ Tujuan saudara menggunakan Media sosial ?, Jawaban responden memilih lebih dari satu jawaban. Empat jawaban terbanyak dari responden adalah untuk melakukan komunikasi antara teman-teman, happy fun (bersenang-senang), menyebarkan informasi dan mencari penghasilan. Gambar 3 , menggambarkan jawaban responden. 


\section{Tujuan Menggunakan Media Sosial}

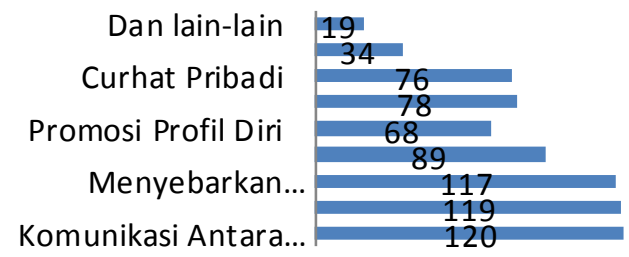

Gambar 3. Tujuan Menggunakan Media Sosial

Pertanyaan tentang “ Apakah yang saudara lakukan pada saat menerima informasi ?. Jawaban responden beragam, tetapi yang paling dominan 46 responden langsung meneruskan kepada pihak lain baik itu secara perorangan, ke publik maupun dalam group mereka. 35 responden melakukan cross check terhadap kebenaran informasi yang mereka terima. Selebihnya mereka menghapus dan mendiamkan informasi yang mereka terima serta menambah/mengganti informasi yang diperoeleh menjadi informasi yang baru. Gambar 4, memperlihatkan ketika responden memperoleh informasi.

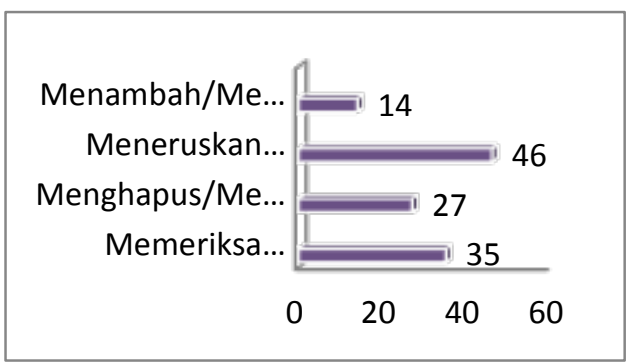

Gambar 4. Yang Dilakukan Responden Ketika Memperoleh Informasi

Pertanyaan tentang “ Menurut anda apa itu "HOAX" ?. Jawaban responden beragam dan memberikan beberapa jawaban intinya bahwa hoax adalah informasi yang tidak dapat dipertanggungjawabkan kebenarannya. Pada gambar 5 menguraikan definisi hoax, dimana jawaban yang sering disebut responden adalah berita yang tidak jelas sumbernya dan jawaban yang cukup menarik dikatakan berita yang menyudutkan pemerintah, baik dari personil sebagai pemimpin lembaga negara maupun pengeloaan pemerintahan.

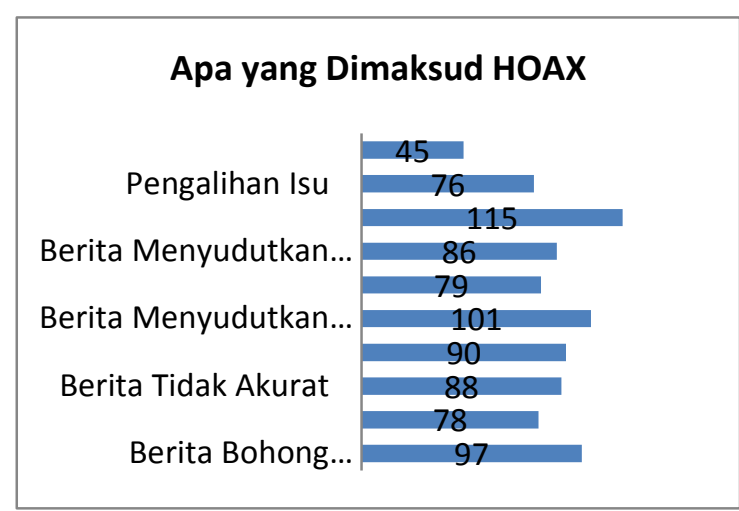

Gambar 5. Jawaban Responden tentang HOAX

Pertanyaan tentang "Apa alasan saudara menyebarkan informasi ?”. Jawaban responden beragam, 44 orang menyatakan agar bermanfaat bagi orang lain, 37 orang untuk mempengaruhi sikap orang lain dan sisanya untuk menjadi terkenal dan memperbanyak follower. Pada gambar 6 diperlihatkan alasan responden menyebarkan informasi.

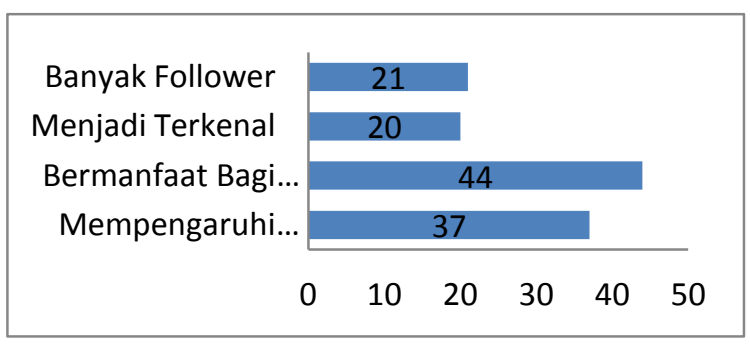

Gambar 6. Alasan Responden Meneruskan Informasi

Pertanyaan tentang "Bagaimana saudara mengecek atau mengklarifikasi informasi yang anda peroleh ?’. Jawaban responden cukup menarik, 54 responden melakukan check ricek melalui media sosial yang sama, 42 orang melalui search enngone internet (google) dan sisanya melalui media massa dan menanyakan orang yang lebih paham. Pada gambar 7 memperlihatkan gambaran responden melakukan croscheck terhadap informasi yang diterima. 


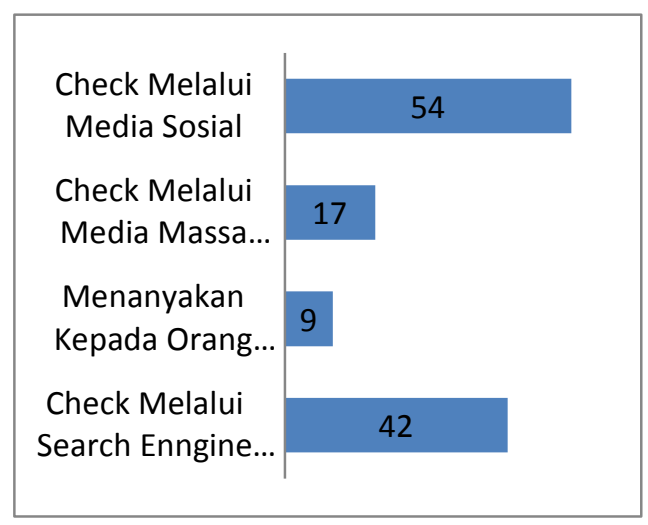

Gambar 7. Cara Responden Mengecek Kebenaran Informasi

Pertanyaan tentang “ Informasi hoax yang anda peroleh dalam bentuk apa ?’. Jawaban responden menyatakan 62 responden lebih banyak menerima dalam bentuk tulisan dan gambar, 29 responden memperoleh dalam bentuk tulisan, 20 responden menerima dalam bentuk gambar dan sisanya dalam bentuk video.

Pertanyaan tentang "Dimedia apa, anda sering menerima informasi hoax?”. Jawaban responden cukup beragam, 56 responden menyatakan melalui media sosial, 48 responden menyatakan memlalui aplikasi chatting (WA, Line, Telegram) dan sisanya melalui situs, media massa dan email. Pada gambar 8 memperlihatkan secara keseluruhan jawaban responden terhadap media.

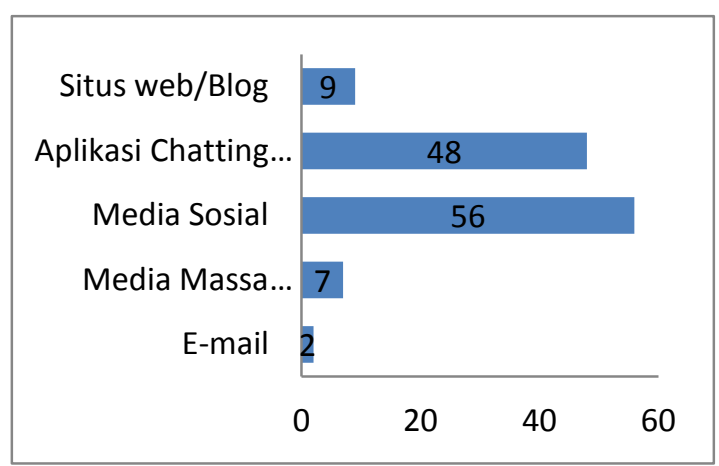

Gambar 8. Media Penyebaran Informasi Hoax

Pertanyaan tentang “ Apa content informasi HOAX yang anda peroleh ?”. Jawaban responden cukup beragam, diantaranya mengenao sosial politik, agama, etnis/kesukuan, penipuan, makanan, bencana, berita duka, candaan dan iptek. Pada gambar 9 menggambarkan jawaban responden tentang content informasi hoax yang diperoleh.

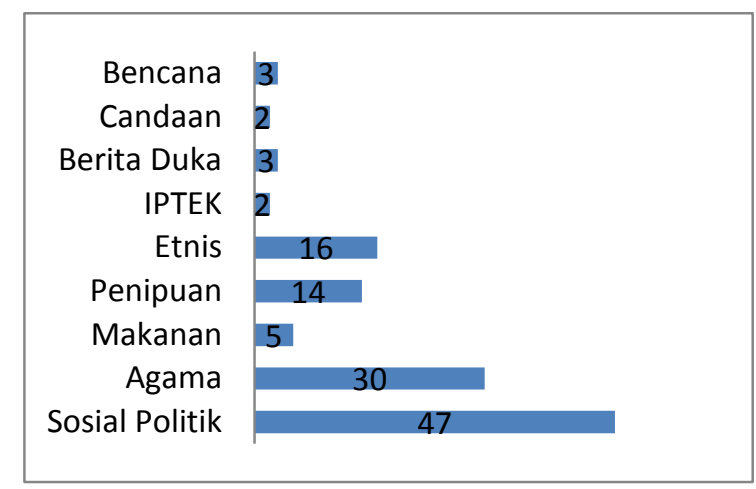

Gambar 9. Content Informasi HOAX

Pertanyaan tentang "Menurut anda sejauh mana dampak informasi HOAX terhadap kehidupan berbangsa dan bernegara ?”. Jawaban responden beragam dalam menjelaskan dampak akibat informasi hoax. Jawaban terbanyak dimana Hoax dapat memecah bangsa, dapat menimbulkan permusuhan antar agama, menimbulkan kecurigaan antar elemen bangsa, menghambat pembangunan, saling mencurigasi antar etnis tertentu, adanya intimidasi dari pihak tertentu dan lain sebagianya. Secara lengkap dapat diperlihatkan pada gambar 10 .

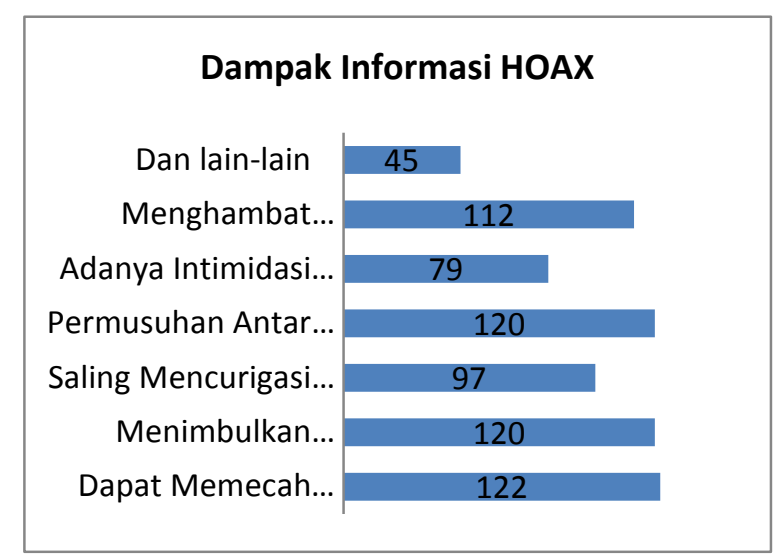

Gambar 10. Dampak Informasi HOAX

Pertanyaan tentang "Menurut anda apa alasan pihak tertentu menyebarkan informasi HOAX ?”. Jawaban responden 
beragam, dimana responden menyebutkan beberapa alasan mengapa pihak tertentu menyebarkan informasi hoax. Jawaban tersebut diataranya ingin merubah atau mempengaruhi opini publik, supaya menjadi viral dimedia sosial, ingin merubah kebijakan pemerintah yang tidak sesuai, ingin menghakimi atau m,encela perbuatan personal yang melanggar hukum, mendukung elmen masyarakat tertentu, persaingan bisnis, minimnya tindakan hukum. Secara lebih lengkap dapat diperlihatkan pada gambar 11 .

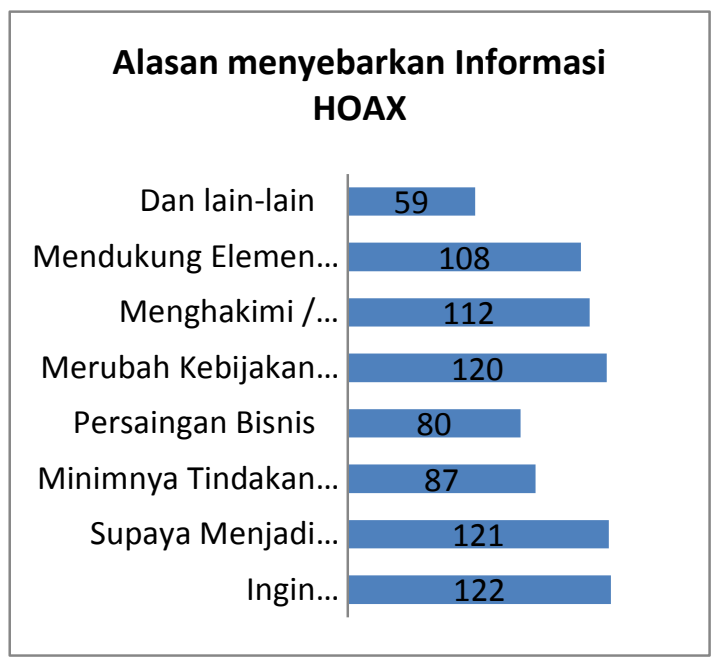

Gambar 11. Alasan Menyebarkan Informasi HOAX

Pertanyaan tentang "Menurut anda cara yang paling efektif untuk menghambat penyebaran informasi $H O A X$ ?”. Jawaban responden beragam, dimana responden menyebutkan beberapa cara menghambat menyebaran informasi hoax. Jawan responden dianataranya melakukan croscheck/klarifikasi terlebih dahulu, memberikan edukasi kepada masyarakat, ada kontrol /pengawasan dari pihak keluarga, tidak mudah terprovokasi, diacuhkan saja, melakukan pemblokiran oleh pihak yang berwewenang, melakukn flagging dan sebagainya. Secara lebih lengkap dapat dilihat pada gambar 12 .

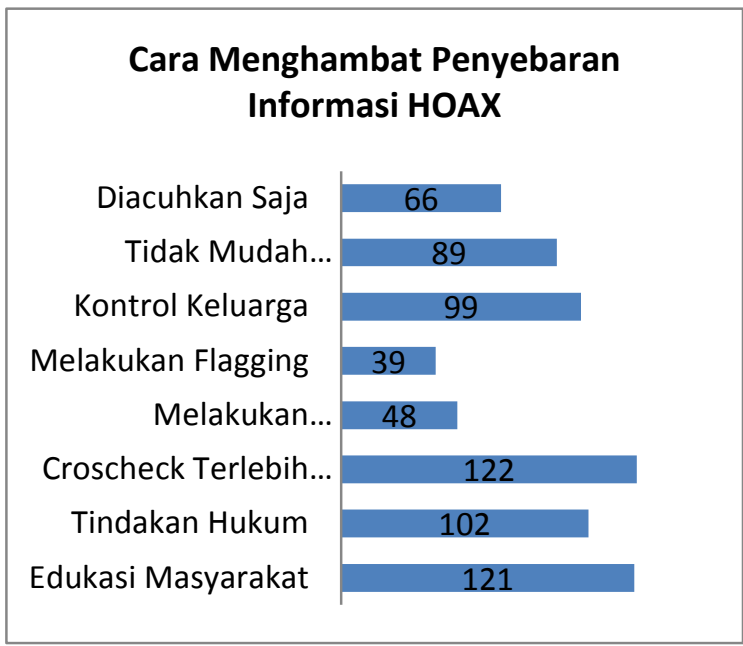

Gambar 12. Cara Menghambat Penyebaran Informasi HOAX

Pertanyaan tentang “ Siapa yang bertanggung jawab menghambat penyebaran informasi $H O A X$ ?”. Jawaban responden beragam, dimana responden menyebutkan ada beberapa pihak yang bertanggung jawab dalam penyebaran informasi hoax. Jawaban responden diantaranya, pribadi masingmasing personal, pihak keluarga, pihak berwajib, pemerintah, alim ulama/pemuka agama, komunitas masyarakat dan sebagainya. Secara lebih lengkap dapat dipelihatkan pada gambar 13 .

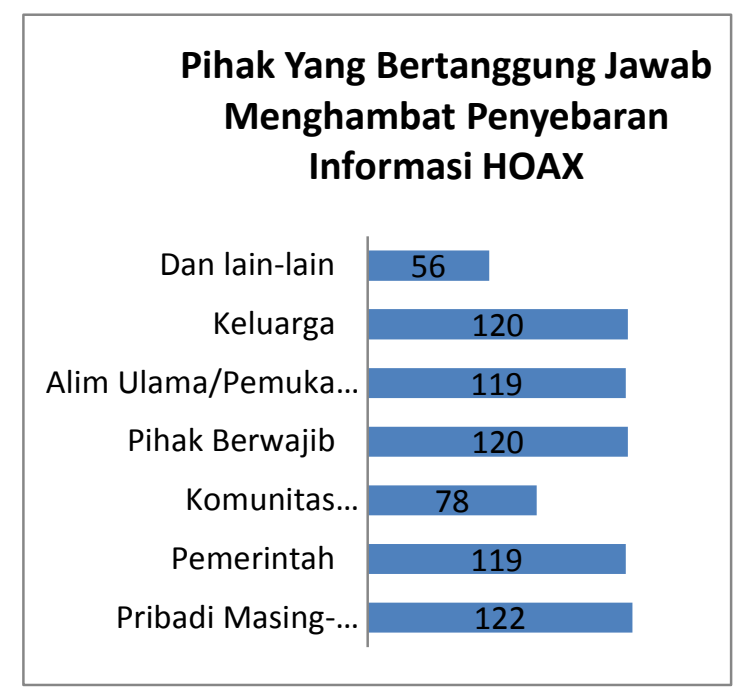

Gambar 13. Pihak yang Bertanggungjawab Dalam Menghambat Penyebaran Informasi HOAX 


\section{PEMBAHASAN}

Keberadaan media sosial sudah bukan lagi hal yang aneh dan dianggap tabu, karena hampir semua orang pengguna internet menggunakan media sosial, bahkan satu orang bisa mempunyai banyak akun untuk mengakses berbagai situs media sosial, dari hasil penelitian juga memperlihatkan reponden memiliki lebih dari satu account. Media sosial memberikan kemudahan bagi user atau membernya dengan mudah berpartisipasi, berbagi, dan menciptakan isi baik dalam bentuk blog, jejaring sosial, wikipedia, forum, atau pun dalam bentuk komunitas yang di bangun secara online dalam ruang virtual. Semakin mudahnya fasilitas untuk mengakses internet membuat perkembangan media sosial sangat pesat bahkan banyak orang yang memanfaatkan media yang satu ini untuk keperluan pribadi, bisnis dan penyebaran informasi Hoax. Merujuk pendapat yang dikemukan oleh Buente dan Robbin (2008), dimana mereka melakukan studi atau investigasi tentang tren aktivitas-aktivitas informasi internet warga Amerika antara Maret 2000 hingga November 2004. Hasil riset tersebut ada empat dimensi kepentingan penggunaan internet yaitu informasi (information utility), kesenangan (leisure/fun activities), komunikasi (communication), dan transaksi (transaction). Hasil ini dapat menggambarkan bahwa aktivitas pengguna media sosial di lingkungan civitas akademik Universitas Presiden meliputi empat dimensi sesuai dengan hasil temuan Buente dan Robbin (2008). Hal ini menunjukkan ada perilaku pengguna yang positif bilamana aktivitas yang dilakukan pengguna sesuai dengan lingkungan kampus, dimana penggunaaan internet atau secara spesifik media sosial harus disikapi secara bijak. Penyebaran berita palsu yang marak terjadi ini jika dikaitkan dengan etika pada internet adalah penyalahgunaan freedom of speech. Freedom of speech ini berasal dari negaranegara yang memiliki tradisi liberal yang menyalahkan apabila seseorang mempunyai batasan dalam mengemukakan pendapat dan memiliki fungsi masing-masing individu pada komunitas dapat mengemukakan pendapat, menyalahkan seseorang, memuji seseorang dll sebebas-bebasnya pada suatu komunitas (Floridi, 2010). Dengan berkembangnya media sosial yang dapat melintasi antar negara atupun benua, masingmasing budaya dan tradisi tidak akan berperan dalam hal pembatasan penyebaran informasi ini. Berawal dari biasnya budaya tersebut, hak Freedom of Speech seringkali disalahartikan dan salahgunakan untuk menciptakan berita hoax yang bertujuan memang untuk membuat sensasi pada media sosial tersebut atau memang sengaja agar pengguna internet dapat mampir pada website sang pembuat berita hoax tersebut agar meraup keuntungan dari jumlah pengunjung yang banyak pada website-nya.

Dari hasil penelitian juga menunjukkan perilaku pengguna media sosial paham terhadap informasi hoax, alasan, dampak, cara mengatasi serta cara tanggung jawab dalam penyebaran informasi hoax. Menurut pandangan psikologis, ada dua faktor yang menyebabkan pengguna cenderung mudah percaya pada informasi hoax. Pada dasarnya perilaku pengguna lebih cenderung percaya informasi hoax, jika informasinya sesuai dengan opini atau sikap yang dimiliki (Respati, 2017). Hasil penelitian juga mendukung pendapat David Harley dalam buku Common Hoaxes and Chain Letters (2008), yang mengidentifikasikan hoax secara umum. Pertama, informasi hoax biasanya memiliki karakteristik surat berantai dengan menyertakan kalimat seperti "Sebarkan ini ke semua orang yang Anda tahu, jika tidak, sesuatu yang tidak menyenangkan akan terjadi”. Kedua, informasi hoax biasanya tidak menyertakan tanggal kejadian atau tidak memiliki tanggal yang realistis atau bisa diverifikasi, misalnya "kemarin" atau "dikeluarkan oleh..." pernyataan-pernyataan yang tidak menunjukkan sebuah kejelasan. Kemudian yang ketiga, informasi hoax biasanya tidak memiliki tanggal kadaluwarsa pada peringatan informasi, meskipun sebenarnya kehadiran tanggal tersebut juga tidak akan membuktikan apa-apa, tetapi 
dapat menimbulkan efek keresahan yang berkepanjangan. Keempat, tidak ada organisasi yang dapat diidentifikasi yang dikutip sebagai sumber informasi atau menyertakan organisasi tetapi biasanya tidak terkait dengan informasi..

Perasaan positif akan timbul dalam diri seseorang jika opini atau keyakinannya mendapat pengakuan dan cenderung tidak akan mempedulikan apakah informasi yang diterimanya benar atau salah. Mereka akan untuk menyebarkan kembali informasi tersebut tanpa ada filter. Kondisi ini diperparah jika si penyebar informasi hoax memiliki pengetahuan yang kurang dalam memanfaatkan internet. Kecendrungan terlalu lama menggunakan internet untuk mencari informasi sehingga dimungkinkan akan mengalami information overload. Sehingga kerapkali terjadi informasi Hoax mudah mereka terima dan disebarkan kepada pihak lain tanpa terlebih dahulu melihat manfaat dan mudharatnya bagi orang lain. Kecendrungan lainya, perilaku pengguna hanya melihat judul berita (head line) tanpa melihat isi dari berita tersebut dan mereka langsung berpendapat bahwa informasi tersebut sudah benar. Apalagi didukung orang mengirim informasi tersebut dari teman yang dipercaya atau dari media yang kredibel, sehingga langsung memberi komentar berdasarkan judul berita. Disisi lain ada ada gejala orang di media sosial untuk ikut memberikan komentar pada suatu tema agar bisa dianggap mengerti. Sebuah berita yang menjadi trending topic atau viral di media punya kecenderungan disebarkan lebih banyak, tanpa adanya upaya verifikasi terlebih dahulu, agar tidak terlihat ketinggalan. Dengan menyebarkan satu berita yang ramai dibicarakan orang bisa merasa tahu dan dianggap punya legitimasi sebagai orang yang berpengetahuan luas.

Perilaku penyebaran hoax melalui media sosial sangat dipengaruhi oleh pembuat berita baik itu individu maupun berkelompok, dari yang berpendidikan rendah sampai yang tinggi, dan terstruktur rapi. (Lazonder, Biemans, \& Wopereis, 2000) menunjukkan bahwa terdapat perbedaan antara seseorang yang memiliki keahlian khusus dalam menggunakan search engine dengan orang yang masih baru atau awam dalam menggunakan search engine. Pengguna yang memiliki pengalaman lebih banyak dalam memanfaatkan search engine, akan cenderung lebih sistematis dalam melakukan penelusuran dibandingkan dengan yang masih minim pengalaman (novice).

Informasi Hoax sering disebarluaskan dan bersumber dari kabar bohong dan dibuat dalam satu jaringan sosial untuk menjaga kepentingan pribadi maupun kelompok. Seringkali secara sadar pengguna media sosial menyebarkan kebohongan untuk membantu agenda yang direncanakan. Penyebar Hoax bisa dari kalangan personal, komunitas, korporasi, lembaga negara, dan militer kerap membuat propaganda kebohongan agar kepentingan mereka bisa terjaga. Informasi Hoax dibuat agar khalayak ramai tak lagi fokus pada masalah sebenarnya dan selanjutnya akan terjebak pada hal-hal bombastis yang bukan jadi permasalahan pokok. Posisi penyebar informasi Hoax yang dianggap kredibel menjadikan pengguna merasa yakin bahwa informasi itu benar dan menjadikan itu suatu kebenaran dan dapat disebarluaskan tanpa diperiksa kembali.

Pada dasarnya setiap pribadi memiliki tanggungjawab terhadap informasi yang mereka terima. Perilaku pengguna sosial media memiliki perasaaan emosional ketika memperoleh kabar buruk atau kabar tragedi seseorang dan merasa punya tanggung jawab moral untuk berbagi. Saat itu tidak lagi mempedulikan apakah itu hoax atau tidak ?. Di media sosial, orang merasa punya beban untuk berbagi penderitaan agar bisa menjadi pelajaran bagi pengguna lain ataupun ingin melepaskan beban agar merasa lebih baik. Pengguna menginginkan komentar ataupun like dan seringkali dibagikan tanpa ada verifikasi terlebih dahulu.

Kebiasaan perilaku pengguna media sosial untuk tidak mau dipersalahkan apabila informasi tersebut Hoax, mereka 
menambahkan kata-kata "dari grup sebelah" sebagai tindakan preventif agar jika berita itu bohong. Perilaku ini merupakan upaya lepas tangan dari tanggung jawab kebenaran. Informasi dari broadcast sangat susah diverifikasi dan dilacak siapa penyebar awalnya.

\section{Peran Pemerintah Dalam Berita Hoax}

Peran pemerintah dalam fenomena berita hoax dipaparkan dalam beberapa pasal yang siap ditimpakan kepada penyebar hoax tersebut antara lain, KUHP, Undang-Undang No.11 Tahun 2008 tentang Informasi dan Transaksi Elektronik (ITE), Undang-Undang No.40 Tahun 2008 tentang Penghapusan Diskriminasi Ras dan Etnis. Tidak hanya itu, penyebar berita hoax juga dapat dikenakan pasal terkait ujaran kebencian dan yang telah diatur dalam KUHP dan UU lain di luar KUHP. Pada Januari 2017 pemerintah melakukan pemblokiran terhadap 11 situs yang mengandung konten negatif, namun kasus pemblokiran tersebut tidak sampai menyentuh meja hijau. Beberapa kasus di Indonesia terkait berita hoax telah memakan korban, salah satunya berita hoax akan penculikan anak yang telah tersebar di beberapa media sosial dan menyebabkan orang semakin waspada terhadap orang asing. Dari hukum yang dibuat oleh pemerintah, jumlah penyebar hoax semakin besar tidak berbanding lurus dengan jumlah persidangan yang seharusnya juga besar. Dengan masih belum mampu menjerat beberapa pelaku hoax, sangat disayangkan pemerintah hanya melakukan pemblokiran terhadap situs-situs hoax. Sementara si pembuat berita hoax masih dapat terus berproduksi melakukan ancaman dan memperluas ruang gerak. Semakin berkembangnya hoax di masyarakat juga mendorong beberapa pihak dalam mulai melawan penyebaran hoax. Sejak tahun 2016 lalu, Facebook mulai memperkenalkan fitur yang memungkinkan sebuah link artikel yang dibagi melalui Facebook akan diberi tanda Dispute (ditentang) bagi artikel-artikel yang ditengarai menyebarkan informasi yang dapat diragukan kebenarannya.Aplikasi pesan instan populer seperti Line juga mulai memerangi hoax dengan aktif menyebarkan informasi melalui Line New manakala suatu hoax mulai ramai di tengah masyarakat. Selain platform sosial media tersebut, masyarakat juga mulai menggagas program Turn Back Hoax, dimana suatu informasi hoax akan diidentifikasi dan dipublikasi mengenai kebenarannya melalui berbagai media, diantaranya grup Facebook dan melalui website Turn Back Hoax sendiri.

Untuk mencegah penyebaran Hoax dapat dilakukan dengan literasi media. Literasi media adalah perspektif yang dapat digunakan ketika berhubungan dengan media agar dapat menginterpretasikan suatu pesan yang disampaikan oleh pembuat berita. Literasi media adalah pendidikan yang mengajari khalayak media agar memiliki kemampuan menganalisis pesan media, memahami bahwa media memiliki tujuan komersial/bisnis dan politik sehingga mereka mampu bertanggungjawab dan memberikan respon yang benar ketika berhadapan dengan media (Rochimah, 2011, p. 28). Orang cenderung membangun sebuah perspektif melalui struktur pengetahuan yang sudah terkonstruksi dalam kemampuan menggunakan informasi (Pooter, 2011). Juga dalam pengertian lainnya yaitu kemampuan untuk mengevaluasi dan menkomunikasikan informasi dalam berbagai format termasuk tertulis maupun tidak tertulis.

\section{Kesimpulan dan Saran}

Informasi Hoax sengaja dibuat untuk mempengaruhi publik dan kian marak lantaran faktor stimulan seperti isu sosial politik dan SARA, namun penerima hoax cukup kritis karena mereka telah terbiasa untuk memeriksa kebenaran berita. Ini artinya sudah bagus, tinggal bagaimana mencegah kelompok silent majority berpindah ke haters.

Pencegahan kuatnya arus informasi hoax dapat dilakukan dengan meningkatkan literasi masyarakat melalui peran aktif pemerintah, pemuka masyarakat dan komunitas, menyediakan akses yang mudah kepada sumber informasi yang benar atas 
setiap isu hoax, melakukan edukasi yang sistematis dan berkesinambungan serta tidakan hukum yang efektif bagi penyebarnya

Sebaiknya dilakukan pembekalan kepada masyarakat mengenai pengetahuan akan internet sehat dengan literasi media sehingga dapat mengenali ciri-ciri berita hoax, dan penerima berita dapat mengakses, menganalisis, mengevaluasi, dalam mengambil makna dari suatu berita

\section{DAFTAR PUSTAKA}

Andreas M Kaplan, \& Michael Haenlein. (2010). Users of the World, Unite! The Challenges and Opportunities of Social Media. Business Horizons, 53, hlm 5968.

Buente W ,dan Robbin A. 2008. “Trends in Internet Information Behavior: 20002004”.

Journal of the American Society for Information Science. Amerika Serikat [US]

Caleb T. Carr dan Rebecca A. Hayes (2015), Social Media: Defining, Developing, and Divining, Atlantic Journal of Communication, Volume 23, 2015

Convelo G. Cevilla, 1993, Pengantar Metode Penelitian, Universitas Indonesia, Jakarta

Choo, C. W., Detlor, B., \& Turnbull, D. (1999). Information Seeking on the Web-An Integrated Model of Browsing and Searching. ASIS Annual Meeting, 5(2), 1-15. https://doi.org/10.5210/fm. v5i2.729

Chordhry, A. ,2017,. Facebook Launches A New Tool That Combats Fake News. Retrieved May 4, 2017, from https://www.forbes.com/sites/amitchow dhry/2017/03/05/facebook-fake-newstool/\#460b19677ec1
Floridi, L, 2010, The Cambridge Handbook of Information and Computer Ethics. Cambridge: Cambridge University Press.

Harley, D, 2008. Common Hoaxes and Chain Letters. San Diego: ESET, LLC

Jamaludin, F, 2016, . 773 ribu situs diblokir Kemkominfo setahun, pornografi paling banyak. Merdeka.com. Retrieved from https://www.merdeka.com/teknologi/77 3-ribu-situs-diblokir-kemkominfosetahun-pornografi-paling-banyak.html

Jan H. Kietzmann, etl ,2011, Social media? Get serious! Understanding the functional building blocks of social media, Business Horizons 54, 241—251

Kotler, Philip, dan Kevin Lane Keller, 2009. Manajemen Pemasaran Jilid 1, edisi Ketiga Belas, Terjemahan Bob Sabran, MM. Penerbit Erlangga, Jakarta

Lazonder, A. W., Biemans, H. J. a, \& Wopereis, I. G. J. H., 2000,. Differences between novice and experienced users in search information on the World Wide Web. https://doi.org/10.1002/(sici)10974571(2000)51:6<576::aid-asi9>3.0.co;27

Pooter, J. W. ,2011,. Media literacy (7th ed.). California: SAGE. https://doi.org/ 10.1332/policypress/9781847424396.00 $\underline{3.0018}$

P.N. Howard dan M.R Parks, 2012, American Behavioral Scientist, Vol. 45 No. 3, November 2001 383-404

Pratama, A. B. ,2016, Ada 800 Ribu Situs Penyebar Hoax di Indonesia. CNN Indonesia. Retrieved from http://www.cnnindonesia.com/teknologi/ 20161229170130-185-182956/ada-800ribu-situs-penyebar-hoax-di-indonesia/ 
Respati, S. ,2017, Mengapa Banyak Orang Mudah Percaya Berita "Hoax"? Kompas.com. Retrieved from http://nasional.kompas.com/read/2017/0 1/23/18181951/mengapa.banyak.orang. mudah.percaya.berita.hoax.

Rochimah, T. H. ,2011,. Gerakan Literasi Media: Melindungi Anak-Anak dari Gempuran Pengaruh Media. In D. Herlina, Gerakan Literasi Media Indonesia (pp. 18-36). Yogyakarta: Rumah Sinema.

Setiawan, A. B. ,2012, Penanggulangan Dampak Negatif Akses Internet Di Pondok Pesantren Melalui Program Internet Sehat Overcoming Negative Impact of Internet Access in Pondok Pesantren Through Healhty Internet Program.

Sholihuddin, M. (n.d.). Pengaruh Kompetisi Individu (Individual Competence) Terhadap Literasi Media Internet Di Kalangan Santri. Unair. https://www. merriam-webster. com) 